\title{
Max Weber's Sociology of Law Applied to a Case of Judicial Intervention into State-Sanctioned Inmate
}

\author{
Abuse \\ J Forbes Farmer, Ph.D. \\ Professor, Sociology Department, Franklin Pierce University, 40 University Drive, Rindge, \\ New Hampshire, USA. Email: Farmerjf@Franklinpierce.edu
}

Accepted: July 15, 2013 Published: July 31, 2013

Doi:10.5296/jsr.v4i2.3966 URL: http://dx.doi.org/10.5296/jsr.v4i2.3966

\begin{abstract}
Applying Weber's classical sociology of law as the theoretical lens, the author revisits a famous judicial intervention (Ruiz v. Estelle 1980) aimed at curtailing the cruel and unusual punishment suffered by indigent and uneducated inmates and perpetrated by prison staff and inmate overseers, know as "building tenders." Marquart and Crouch $(1984 ; 1985)$ and Ekland-Olson (1986) wrote case studies of this intervention into the activity at a unit of an American state prison system on data they obtained from participant observation, formal and informal interviews with correctional officers and inmates, and institutional documents (e.g. log books, memos and inmate records). The following article follows the outline of the series of events described in these case studies and adds a Weberian explanation of the changing forms of justice that are both rational and irrational, formal and substantive.
\end{abstract}

\section{Keywords}

Sociology of law, judicial intervention, verstehen, social action, prison reform

\section{Introduction}

\subsection{The Sociology of Law}

While there are widely different sociological perspectives on law, a general sociology of law aims at understanding the factors that influence legal systems (Vago 2012:44) and the meaningful behavior of the members of a group in relation to the laws in force and to determine the nature of the belief in their validity or in the order which they have established. It, therefore, seeks to determine the extent to which the rules of law are observed, and how individuals orient their conduct in relation to those rules (Freund 1968:246). Sociologists and legal theorists generally agree that the components of law and society are complex and interconnected. Beyond that, however, the theorists disagree in their interpretations of how 
changes in law can affect social change. A brief comparison of the legal theories of the classical sociologists Marx, Durkheim and Weber will serve as an example of these differences.

Karl Marx thought that a society's mode of production drove the way people related to the productive technology. A change in former would change the latter, and the society's type of law was meant to guarantee that relationship. "Law was a product of evolving economic forces" (Vago 2012:49) and an upper class tool to maintain control and dominance over the lower class (Marx 1978; Vago 2012:49). His ideas about law, laid out in the Manifesto of the Communist Party (1978), represent the conflict perspective that focuses on tension between groups and individuals.

For Emile Durkheim, who represents the structural-functional approach to law and outlined his views in The Division of Labor in Society (1964), the type of law a society practiced was a measurement of the type of solidarity in that society (Vago 2012:51). Laws were repressive in closely knit societies and restitutive in societies with a complex division of labor. Punishment served a different purpose under these different societies. It was meant to protect social solidarity in the former and function as a form of restitution and reparation in the later. Thus, "For Durkheim, the law is a symbol of social life, and so primarily of its culture" (Treiber 2012:133).

As for Max Weber, the theory of law that this lawyer and classical sociologist spelled out in Economy and Society (1968) involves four ideal types of law. Substantive irrational law exists when a case is decided, not by general rules, but by emotional, personal, ethical or political bias and a lack of procedural uniformity (Osanloo 2006:16), like Weber's "Khadi justice" (Qian 2010:34). Formal irrational law exists when rules are based on supernatural forces. Substantive rational law is present when rules are applied that are not based on legal sources, like the bible. Formal rational law involves the equal application of logical and consistent rules that are independent from religious and other normative criteria, such as current American law (Vago 2012:50). These ideal types of law, considered the "analytical keystones of his (Weber's) sociology of law" (Sahni 2009:211), are then connected to Weber's ideal types of meaningful action (instrumentally rational, value-rational, affectual and traditional) (Chaudhry 2011:258; Weber 1968). While Durkheim saw law as culture, Weber conceived it as an order (Treiber 2012:133). This sophisticated sociology of law has been considered unsurpassed in its historical scope and ambition (Chaudhry 2011:249; Vago 2012:50), and because of this, Weber remains one of the most central and influential legal and sociological theorists of our time. According to Bartels (2009), Weber's ideal typical methodology is a "conceptually pure model against which concrete historical events and patterns can be understood" (451).

\subsection{A Brief History of Inmate Abuse in Texas}

Prior to 1980, the Texas Department of Corrections had managed to maintain its traditional authoritarian prison systems with little concern for the continuously growing, nationwide 
litigation over prisoner rights (Campbell 2011:6; Price and Coleman 2011:44). They had even ignored many of the specific Texas prison condition statutes (Trulson and Marquart 2002:753). The result was that the department operated within its own "law." This "law" had apparently gone either unchallenged or unsuccessfully challenged from the early 1960's until 1972 when the largest prisoner suit in the history of America (Campbell 2011:6; Price and Coleman 2011:57) was filed by eight inmates in the Texas penal system. The petitioners believed that their Eighth (prohibits cruel and unusual punishment) and Fourteenth (requires equal protection under the law) Amendment rights were being violated thru the continued use of many official and unofficial methods of prisoner control which comprised penal "law" at their respective institutions of confinement (Reynolds 2002:1). Despite the suit, de facto "law" continued unchanged until in Ruiz v. Estelle (1980) a federal district judge ruled unconstitutional these methods of coercion which had included administrative use of special inmates known as "building tenders" (hereafter referred to as BTs) to control other inmates. [Ruiz was an inmate at Eastham and Estelle was the Director of the Texas Department of Corrections.] Max Weber might not have been surprised that Ruiz v. Estelle would result, as it did, in escalated inmate-inmate and inmate-correctional officer (hereafter referred to as COs) violence throughout the Texas penal system. He had written that "the structure of every legal order directly influences the distribution of power, economic or otherwise, within its respective community" (Weber 1946:180).

In the USA there was a large maximum security prison, the Eastham Unit of the Texas prison system, that housed almost 3,200 older, recidivist inmates (47\% Black, 36\% White, 17\% Hispanic) and had a reputation for tight disciplinary control (Marquart and Crouch 1984:493; Marquart and Crouch 1985:559). The prison was known as the "end of the road for prisoners" (Price and Coleman 2011:56). The legal order at the Eastham Unit controlled the social relations there and when the legal order was changed by Ruiz v. Estelle (1980), a redistribution of power was to follow. Marquart and Crouch (1985) and Ekland-Olson (1986) have provided focused case studies of the Ruiz ruling as it affected the Eastham Unit. The authors of these studies followed an often used social control model to explain the overcrowded conditions at Eastham and the violent results of those conditions. What follows is an attempt to use a Weberian model to explain the impact, understanding and emergence of "law" at Eastham. "Law," in general, was described by Weber as "an `order' endowed with certain specific guarantees of the probability of its empirical validity" (1968:313).

\subsection{Weber in Brief}

In keeping with Weber's positivistic tradition, the following sociological analysis explains the relationship between the activities and values that define the Eastham Unit before, during and after the Ruiz trial, as seen by the inmates, the Court and the prison administration. This is an evolutionary analysis which recognizes, as Weber did, that it is conflicting values and ideologies which, converted into action, serve as the force behind the creation of law and social change. Following Weber's lead, this study concerns "itself with the interpretive understanding of social action and thereby with a causal explanation of its course and consequences" (Weber 1968:4). Most of the treatment here is of collective administrative and 
inmate action and subjective meaning, which was Weber's later focus and central to his theoretical sociology (Stout 2010:495; Swedberg 2003:283). Treating collective social actors as individual agents was justified by Weber if they were "resultants and modes of organization of the particular acts of individual persons" (1968:13). This "verstehenian" treatment, however, will also give parallel attention to some Weberian macro analysis.

\section{Theoretical Orientation}

The action (verifiable as facts) and values discussed in this Weberian sociology of law at Eastham are analogous to the process and normative aspects of law. It is shown how inmates and administration understand and legitimate both process and norms. ("Administration" will be initially used to include all prison personnel including BTs. Ruiz v. Estelle (1980), however, declared them illegal so later usage excludes them.) Both Weber's sociology of law and his definition of law include an interplay of norms and process. "As long as there is a chance that a coercive apparatus will enforce, in a given situation, compliance with those norms, we nevertheless must consider them as 'law'" (Weber 1968:312). Furthermore, he separated public and private law. Both types of law are applicable to the following discussion of the Eastham Unit.

Weber defined public law as "the total body of those norms which regulate state-oriented action, that is, those activities which serve the maintenance, development, and the direct pursuit of the objectives, of the state, objectives which must themselves be valid by virtue of enactment or consensus" (1968:641). This type of law, Weber went on to say, could establish rights of individuals. If we consider the Eastham Unit administration as an agent of the state, it is appropriate to ask what norms regulated its inmate control action. Since the courts had generally maintained remnants of a "hands-off" policy towards the penal system up until Ruiz v. Estelle (1980) (Deitch 2012:236), the prison could still be managed at the discretion of the administration. Thus, since building tendering was overwhelmingly considered necessary for the pursuit of control, it (and related activity by the state) falls under the purview of Weber's "public law." And, as Weber had observed in bureaucracies, definitions, expectations and interpretations of events could take on idiosyncratic meanings (1968:1417-19).

The Eastham administration used BTs to define, create, and remove individual rights of inmates. These rights are what Weber called "private law." Private law was defined as "the totality of those norms which, while issuing from the state, regulate conduct other than state-oriented conduct" (Weber 1968:641). It will be justified later (see Eastham Prior to Ruiz) that inmate conduct controlled by the Eastham staff and BTs was regulated by private law. But, just as it would be somewhat of a mistake to place too much emphasis on the distinction between public and private law, it would also be a mistake to accept these laws as a priori and existing without some connection to value.

In his discussion of legitimate domination, Weber wrote that "any given legal norm may be established by agreement or by imposition, on grounds of expediency or value-rationality or both, with a claim to obedience at least on the part of the members of the organization" 
(1968:217). This interplay between law and value is also explained by Weber in one of his discussions of rationality where he tells us that "the only rational knowledge of values we can have is the empirical knowledge of choices we and others have made" (Trubek 1986:581). It will become evident that the emergence, impact and limitations of "law" at Eastham were due to the individual and collective choices made there and in the court. It will also be recognized that these choices were influenced by cultural conditions (Weber 1947:94) inside and outside of the Eastham Unit.

Thus, in this Weberian analysis, both the public and private law at Eastham can be viewed as being normative and process (action) oriented. Technically, as Weber implies in the above statement on the establishment of legal norms, even the normative aspects of Eastham law are consequences of social action. This means that it is possible to consider law as being normative and action oriented at the same time. Even Weber had to struggle with this problem, but he partly solved it by focusing on ideal types of social action and legal thought. In both instances he described the processes used to determine meaning and choice.

In the case of social action, for example, Weber saw some processes as rational. What he called "instrumentally rational" action was action determined by "expectations as to the behavior of objects in the environment and of other human beings; these expectations are used as 'conditions' or 'means' for the attainment of the actor's own rationally pursued and calculated ends" (1968:24). Eastham's methods of inmate control (building tendering, for instance) is a case of public law which was instrumentally rational. But building tendering could also be "value-rational" action because it was determined by a "conscious belief in the value (of control and expediency) for its own sake" (Weber 1968:25).

The categorization of administrative and inmate action as value-rational, instrumentally rational, affectual or traditional, however, is only part of the present Eastham analysis. Also a part, is Weber's legal thought typology which describes legal processes as being either substantive irrational, formal irrational, substantive rational or formal rational (Weber 1968:655-656). What is important is that these categories reflect processes that are partly determined by individual and collective actors who make conscious choices based on interpretive understandings. And of course at the Eastham Unit there were conflicting ideologies, meanings and interpretive choices of what the norms and processes should be. This ultimately caused law at Eastham to go through three major phases which had numerous consequences. Some of the consequences of these conflicts were intended and others not.

Weber (1968) wrote, "It may, in various ways, be an unanticipated consequence of a course of social action and its relevant conditions that certain types of social relationships (meaning, of course, the corresponding actions) will be adversely affected in their opportunities to maintain themselves or to arise" (40). Many consequences at Eastham certainly might have been anticipated by Weber who knew that unless the ideological base (control and domination of inmates, for example) is changed, then legal reform would not get at the roots of the problems there. 
Weber's macro historical analysis of legal procedure and social structure is commonly presented (i.e. Inverarity 1983; Sahni 2009; Treiber 2012) as the major contribution Weber made to the sociology of law. While Weber's macro insights are significant and are certainly useful in explaining the emergence of law at Eastham, it is equally challenging to apply other pieces of Weber's theoretical understanding of law and society to the changes there. Weber never took on such a specific micro analysis, but he had tackled the relevant issues. What follows is an attempt to pull together some of Weber's contributions in the areas of authority, value, bureaucracy, legitimation, public and private law, individual rights, social action, rationality, and legal thought and make them work, in a way he never did, to explain a case study of change. And fundamental to this explanation is Weber's famous definition of "action" which he used "insofar as the acting individual attaches a subjective meaning to his behavior - be it overt or covert, omission or acquiescence. Action is 'social' insofar as its subjective meaning takes account of the behavior of others and is thereby oriented in its course" (1968:4).

\section{Historical Analysis}

\subsection{The Eastham Unit Prior to Ruiz v. Estelle}

\subsubsection{Substantive Irrationality}

Despite the constitutional advancement of due-process and prisoner rights that occurred in the 1960s, public law at the Eastham Unit of the Texas penal system was still autonomous and de facto. The judicial response to prison activity there, and elsewhere, was characteristically "hands-off" (Deitch 2012:236; Ross 2009:34). This meant that the Eastham administration could maintain its tradition of prison order, stability, control and domination over inmates to legitimate its own control methods. Weber had claimed that law existed when there was a probability that norms would be "upheld by a specific staff of men who (would) use physical or psychical compulsion with the intention of obtaining conformity with the (norms), or of inflicting sanctions for infringement of (them)" (1946:180).

Outside of prison, this staff would be the police, but inside Eastham the most effective means of social control was "building tendering" (Price and Coleman 2011:55). This was a method, dated at least to the 1920s (Ekland-Olson 1986:414), whereby a select group of the older, most feared inmates were given special privileges (e.g., preferred housing, permission to carry weapons, special clothing, extra mobility, immunity from discipline) by the administration to define proper prison conduct for other inmates, feed the staff with information about inmate behavior (Marquart and Crouch 1984;496-499) and enforce this substantively irrational "Khadi justice" (Weber 1968:976). The BT system had been prohibited by a Texas statute, but the statute was ignored by the Department of Corrections (Price and Coleman 2011:58). BTs were given special rights and privileges that were to be respected.

Eastham's determination of its own public law (the traditionally legitimated norms of order and compliance which regulated the action of the BTs as de facto agents of the state pursuing 
the objectives of the state) was quite rational. On the macro level, the use of BTs served as a control mechanism that was end-oriented. By allowing the BTs considerable discretionary authority, the penal decision making power became decentralized. The administration could "both increase daily control within the cell blocks and maximize general stability by ensuring that there (was) never a power vacuum" (Marquart and Crouch 1984:493).

\subsubsection{Information Control}

Prison administrators are well aware that inmate violence can result from power vacuums (Price and Coleman 2011:58; Thomas 1984:217) and while they may condone violence towards inmates, they know that inmate violence towards administration can bring disorder. Thus, the BT system was also pro active in that it prevented inmate insurrection and chaos. It was able to do this through tight discipline and compliance and the passing on of inside information to the staff that, incidentally, were buffered from the ordinary inmates by the BTs who protected the COs from physical abuse (Marquart and Crouch 1984:506). On a more macro level, this use of information control was serving to protect the prison organizational boundaries from outside interference which would result if a riot occurred.

\subsubsection{Irrational, Khadi Justice}

Thus, the administration, including the BTs, held virtually absolute power and was "the law" at Eastham before the Ruiz ruling. Weber had, in general, understood power to be "the chance of a man or a number of men to realize their own will in a communal action even against the resistance of others who are participating in the action" (1946:180). This was the situation at Eastham. The COs and BTs could set vague rules such as those having to do with "agitation and laziness" (Marquart and Crouch 1985:561) and could arbitrarily enforce them while exercising substantial latitude in their own behavior (Price and Coleman 2011:58). CO aggression against inmates, for example, was valued behavior in the $\mathrm{CO}$ subculture. Marquart and Crouch (1985) found that "The willingness to use force was a rite of passage for new officers. Those who refused to fight (inmates) were rarely promoted" (568).

The BTs, who were empowered to carry non-firearm weapons, were essentially immune from disciplinary reports and could get away with a good number of activities which were rule violations to the ordinary inmate (Marquart and Crouch 1984:506). For the BTs, their agreeing to serve as agents of the administration was also rational action. For Weber, "action is rationally evident chiefly when we attain a completely clear intellectual grasp of the action-elements in their intended context of meaning" (1968:5). In addition to the special privileges that went with the job, the BTs could "control other prisoners to protect their own statuses, their marketable influence with key prison officials, and their control over the prison economy and rackets" (Marquart and Crouch 1984:492). By taking no action against the COs and the BTs for their aggressive behavior, the Eastham administration was showing how much it valued order, peace and stability. It was also, in Weber's (1968:959) bureaucratic sense, protecting its identity and social position.

The ordinary (non-BT) inmates were the objects of the administrative aggression and "Khadi 
justice" (Weber 1968:976). While the COs and BTs were regulated by what Weber called public law, they, in turn became the regulators of private law and directed it towards the ordinary inmates at Eastham. It is recalled, to justify the use of "private law" here, that Weber's definition of private law is used to specify norms that are issued from the state (1968:641). Marquart and Crouch (1984:495) make it clear that the BTs are screened, selected, sanctioned, supervised and disciplined by prison authorities and that the use of BTs was overt and official. Weber had noted that "executive powers' may be appropriated, or they may be assigned, in accordance with the regulations of the organization, to specific persons or to individuals selected on the basis of specific characteristics or procedures" (1968:48).

The inmates at Eastham prior to Ruiz v. Estelle (1980) were being whipped, beaten, coerced, divided and controlled, but their social system was orderly. They knew that if they broke the private de facto law laid down by the COs and the BTs that punishment would be swift and sure. The inmates knew what was expected of them and their days were filled with certainty. They were literally living in fear and, therefore, their general compliance with the rules was rational. They valued their own lives. As Weber (1968) had recognized, the motives for obedience "in the majority of cases, are predominantly utilitarian or ethical or subjectively conventional, i.e., consisting of the fear of disapproval by the environment" (314). Inmates stayed clear of the BTs and offered little opposition or challenge to administrative authority.

When inmates got into disputes between themselves, they were settled by fist fights conducted under the supervision of the BTs (Marquart and Crouch 1984:497). In this way inmate-inmate violence was generally avoided, but justice remained substantively irrational. Privately, the inmates were not cognitively legitimating Eastham law, but publicly their compliance helped administrative legitimation. The administration could claim their system of control was working as long as a low level of violence was maintained. The inmates knew that they stood at the low end of the prison caste system and with their acute sense of status degradation they were not likely to impute legitimacy to the forms of social control. Their general compliance with Eastham's public and private law had a calming effect on their lives as well as the life of the institution. This was all to change, however.

Discontent was brewing at other less tightly controlled prisons in the Texas penal system. The United States Supreme Court, in Johnson v. Avery (1969), had weakened the judicial "hands-off" doctrine by mandating that prison administrations could not bar jail house lawyers from furnishing legal assistance to the more illiterate inmates (Champagne 1976:276; Price and Coleman 2011:56). The Court was moving due-process to the legal order of prisons and inmates were not only finally being recognized as individuals but their will, manifested through their litigious action, was being enforced. In 1972, inmates in other Texas prisons filed petitions which were later consolidated into the class action suit Ruiz v. Estelle (Ekland-Olson 1986:404; Justice 1990; Price and Coleman 2011:57). The inmates, with the help of a sympathetic judge (Justice 1990), were taking more control over the creation of inmate rights which were previously imposed by the durability of administrative power. 
3.2 The Eastham Unit during Ruiz v. Estelle: The Transition (1980-83)

\subsubsection{Judicial Intervention}

Pre-Ruiz law, both public and private, at Eastham had been initiated by ideological and behavioral conflict between the powerful and the powerless and was directed at the avoidance of further conflict and the perpetuation of order and stability. The courts and prison administration had valued prison autonomy while the prison administration had valued the effectiveness and efficiency of the BT system. The BTs valued their power and prestige and acted in ways to keep it. Sometimes this even meant policing each other (Marquart and Crouch 1984:505). Since the ordinary inmates had valued survival, their action, like that of the BTs, was aimed at the maximization of their situations. This kind of life at Eastham went on pretty much unchanged even after 1972 when the class action suit was filed.

When the Ruiz v. Estelle (1980) ruling came down, it agreed with the plaintiffs that the Texas Department of Corrections was imposing "cruel and unusual punishment on inmates and that remedial measures were necessary" (Justice 1990; Ware 1982:942). The judge ruled that the Texas Department of Corrections "failed to furnish minimum safeguards for the personal safety of the inmate and as a consequence inmates live in fear in a climate of fear and apprehension by reason of constant threat of violence" (Wolff 2009:2; Justice 1980). The judge mandated changes in disciplinary procedures, staff-inmate ratios and the use of BTs. The "changes were designed to reorganize and strengthen the official control structure within the prison system" (Ekland-Olson 1986:392). The court was asserting its legitimation function and taking law making autonomy away from the prisons. Weber had known that when an order was imposed on an organization it was very common "for there to be a large measure of imposition" (1968:51). According to Freund (1968:247), Weber realized that increased rationalization of law would "not necessarily be accompanied by a growing acceptance of its normative validity."

\subsubsection{A Coercive Apparatus}

Public law was now being passed down from above and the administration at Eastham, fearing loss of control, resisted the court order through both legal action and by noncompliance (Marquart and Crouch 1985:569). Weber (1968) noted that "human action may in the first place be consciously aimed to alter certain social relationships - that is, to alter the corresponding action - or it may be directed to the prevention of their development or continuance" (40). The ideological base needed for the support of legal change within the prison could be found amongst inmates, but not the administration which was sure the end of their control and surveillance methods would result in more inmate-inmate and inmate-staff violence. There had been a status quo maintenance of a "highly effective prison as measured by its low cost, low incidents of reported violence, high rate of inmate employment, and general cleanliness of the prisons" (Price and Coleman 2011:55).

The outside ideological base used in the Ruiz ruling was found in the large number of due-process decisions upholding constitutional rights. "A 'right,' in the context of the 'state,' is guaranteed by the coercive power of the political authorities" (Weber 1968:315). These 
rights finally started to come to the Eastham inmates when state attorneys agreed, in 1982, to start dismantling the BT system and have it eliminated by the beginning of 1983 (Marquart and Crouch 1985:570). For Weber (1968), the idea that someone had a legally prescribed right meant that he has a guaranteed chance by the accepted interpretation of a legal norm, of applying to his interests the assistance of a 'coercive apparatus' readily available for this purpose (315).

The inmates were now legally protected from the physical beatings and constant fear induced by the BTs and COs. To assure those rights, the BTs were reassigned to regular inmate jobs and all their special privileges, power, duties and status was removed. Some of them were housed in protective custody quarters, but most of the former BTs, not fearing retaliation for past deeds, were simply transferred back into the main population. The ordinary inmates were still afraid of these more violence prone men and kept their distance, but they were "glad to be 'free' from the BT system" (Marquart and Crouch 1985:570). And in early 1983, they were also freed from the COs' use of unnecessary force. The COs tested the ruling at first. "No 'carpetbagging lawyers' or `bleeding heart federal judges'" (Brakel 1986:6) were going to tell them what to do. As Garland (2011) put it, the old CO practices and the evasion of the law "subsequently reasserted itself." (793). Weber (1968) knew that "Even the most drastic means of coercion and punishment are bound to fail where the subjects remain recalcitrant. In many spheres such a situation would always mean that the participants have not been educated to acquiescence" (334). After a firing, several probations, demotions and transfers the recalcitrant COs got the message that noncompliance with the court order would not be allowed. The legal order, or what Weber (1968) referred to as a "complex of actual determinants of human conduct" (312), continued to shake.

\subsubsection{Subjective Understandings}

Meanings and subjective understandings of the legal order at Eastham changed from the time of the Ruiz ruling in 1980 until the 1983 disciplining of the noncomplying COs. The Eastham administration went from being the lawmakers to the lawbreakers. They lost their autonomy to legitimate methods of social control and found their 'Khadi justice' replaced with formal rationality. Their position of domination over the inmates, while not being lost completely, was overshadowed by the courts intervention and domination over their administrative actions. Their near absolute power became limited. by the "rights of its subjects" (Weber 1968:652).

Not only did the administration have less control, but it was now being controlled. The BT system which the administration had long thought rational had been ruled illegal. The financial savings the BT system had reaped the prison and the buffering it had provided the COs were now gone. Although many new COs were hired, the inside information about inmate activities and plans that used to reach the administration would not reach them anymore. Everyone in the prison was on the verge of having to make rational decisions based on new sets of consequences or take affectual action (Weber 1968:9) on the basis of value alone when the consequences were not known. 


\subsubsection{Rational Bureaucracy}

By the end of this transitional period, Eastham had become a different place (Marquart and Crouch (1985:572). Decision-making power had become more centralized since BTs were no longer allowed. The decentralized structure at Eastham was dismantled and the prison became more bureaucratic with authority now based on formal procedures. COs and higher administrative personnel had to shoulder more responsibility in the day-to-day running of Eastham, yet they felt a loss of power. They saw themselves as having to share control with the inmates and they became demoralized. Without the BTs to help them, the COs had to spend more time in the cell blocks and work directly with the ordinary inmates.

The social distance the COs had been able to maintain now diminished (Marquart and Crouch (1985:574). Control mechanisms were now means oriented because inmates had rights that had to be protected. Inmates sensed the realignment of power and knew that their power had increased. The staff had lost face and feared inmate retaliation. Weber (1968) noted that "social relationships may be influenced by the creation of differential advantages which favor one type over another" (40). Although Ruiz v. Estelle had imposed formal rationality at Eastham and the mandated changes had taken place, uncertainty ruled the emergence of operational norms and process.

\subsection{The Eastham Unit Immediately after Ruiz v. Estelle}

The transitional period had been a time for the reinterpretation of and adjustment to the fact there were to be no more BTs, more COs, less swift and certain punishment for inmates and more attention being given to inmate rights. The social actors inside Eastham were now faced with a new environment where the traditional sets of consequences and choices had been severely altered. What had not changed, of course, was that this was still a prison that housed 3,200 (Marquart and Crouch 1985:573) of the most hardened inmates in Texas and that the administrative mandate was to keep them under control. Friction between inmates was still going to exist and there remained the traditional split between inmates and COs. What was still uncertain was how life would go on.

\subsubsection{Challenge to Authority}

How were inmates going to solve their differences now that there were no BTs to supervise fist fights? How were inmates going to respond to COs now that they would be confronting each other directly without BT buffers? How were the COs at Eastham going to respond to inmate aggression now that everyone was conscious of inmate rights? Weber (1968) believed that if the application of rules was to be fully rational, specialized training would be necessary (1968:218). But most of the new COs were untrained. The answers to the above questions would be figured out by the actors who would have different rationale and motivations for their behavior.

The Eastham inmates, seeing themselves as the winners in the power redistribution caused by Ruiz v. Estelle, came out of their pre-Ruiz shell of complacency and compliance to become 
bolder and less frightened. Inmates knew the court was on their side to protect their constitutional rights and they figured they could cry foul if the COs tried to use force. No one knew quite how to define "unnecessary" force, but everyone knew that it was prohibited and that the COs could get in trouble for using it. Feeling protected from and more equal to the COs, the inmates began to reject things the way they had been. COs lost control of discipline. For Weber, (1968) "discipline" meant "the probability that by virtue of habituation a command will receive prompt and automatic obedience in stereotyped forms, on the part of a given group of persons"(53). Inmates talked back to the COs, refused to take orders and, in general, challenged the COs' authority.

Inmates became hostile, belligerent, confrontative, and argumentative (Marquart and Crouch 1985:572). They verbally and physically abused the COs so much that the COs became demoralized. The inmates, through their aggressiveness, began to assume the power that they thought they had. What made it easy for the inmates to fill the power vacuum was the fact that the COs, too, felt that the inmates were in control. Social relationships changed and conflict resulted in what Weber (1968) referred to as action "oriented intentionally to carrying out the actor's own will against the resistance of the other party or parties" (38). The prison administration, as the agent of the law and the object of the conflict, did not do much about it.

\subsubsection{Protection of Boundaries}

Marquart and Crouch (1985:573) reported that inmate threats towards and attacks on COs increased by 500 percent from 1981 to 1984 . The COs and administration were afraid that if they called attention to the inmate- $\mathrm{CO}$ violence and hostility that they would be calling attention to their own inability to control the inmates under the constraints of Ruiz. The administration was once again practicing Weber's (1968:1418) old proposition that information control can protect the organization from external scrutiny. Although Ruiz had resulted in a decrease of staff-inmate violence, $\mathrm{CO}$ behavior was under the scrutiny of the court and the COs expected that their actions against the inmates might have to be explained at any time (Marquart and Crouch 1985:572). The COs were caught between the formal legal rationality imposed from the outside by Ruiz v. Estelle and the informal rationality of Eastham's emergent operational policies.

The methods of inmate control that were end-oriented before Ruiz were now means-oriented. Society's rules of law and the adversarial system were now integrated into Eastham's disciplinary procedure at the expense of the administration's long history of near total domination over the inmates. Weber (1968) wrote, "Formal justice is thus repugnant to all authoritarian powers, theocratic as well as patriarchic, because it diminishes the dependency of the individual upon the grace and power of the authorities" (812). Inmate rights that had once been granted by COs and BTs and informally legitimated through an appeal to traditional control and efficiency had now been granted by the court and legitimated by the Constitution. All the due-process privileges allowed by the legal system were available to the inmates. They could cross-examine COs, call witnesses and obtain legal counsel. 


\subsection{3 "Iron Cage" or Progress}

Was this increased rationality bringing improvements to Eastham? Weber thought the formal rationality of the legal system was an evolutionary progression towards improvement and liberalism. "Progression" would have to be used in Weber's (1949:39) "technical" sense, as opposed to "evaluative", as will shortly be discussed. Kidder (1983:189), for example, thought Weber "considered formal rationality to be the most modern and admirable form of law." Weber paid considerable attention to the significance of individual freedoms and he thought formal law could preserve those freedoms by providing a framework, like the law of contract (Weber 1968:729), where choice could be protected.

Formal rational law could use value-free techniques and keep politics from the adversarial arena because it guarantees the "freedom for the interested parties to represent their formal legal interests" (Weber 1968:812). Other researchers (Kronman 1983; Trubek 1986) believe that the gradual rationalization of law was seen by Weber as another example, like bureaucracy, of an iron cage, "a shell of bondage which man will perhaps be forced to inhabit some day, as powerless as the fellahs of ancient Egypt" (Weber 1968:1402). The post-Ruiz situation at Eastham prison seemed to reflect both these interpretations of Weber.

\subsubsection{Uncertainty Ruled}

Discipline there evolved from pre-Ruiz arbitrariness, where BTs ruled the swiftness and certainty of punishment, to post-Ruiz legalistic due-process. Technically, one's fate should have been calculable since authority was based on formal procedures. The post-Ruiz reality, however, may have been formally rational, but it was also informally irrational. Not only did the COs, fearing inmate physical and legal retaliation, hesitate to enforce the rules, but there were no more BTs to supervise fist fights. This meant that inmates took it upon themselves to solve their own differences, and they did this in any domineering manner and at any time they wished. Weber (1968) recognized this possibility when he wrote, "The existence of domination turns only on the actual presence of one person successfully issuing orders to others; it does not necessarily imply either the existence of an administrative staff or, for that matter, of an organization" (53).

Discipline at Eastham was delayed and uncertain and the rate of inmate-inmate violence increased regularly there from 1981 to 1984 (Marquart and Crouch 1985:573). While ordinary inmates before Ruiz used to live in fear of BTs but in an orderly environment, they now lived in fear of each other and in an uncertain environment. Administrative control which had been pro-active prior to Ruiz was now reactive. Law in the formal sense was under the authority of the administration, but in the informal sense it was controlled by the inmates. Weber thought that legal progress would be retarded if the population failed to keep up with formal rationality. Inmates at Eastham seem to have accepted formal rationality as it applied to staff-inmate justice, but had not legitimized it for controlling their own inmate-inmate violence which was still handled by "Khadi justice." Inmate-staff infractions were handled by either formal rationality or no justice at all. 
While living in fear, however, the inmates and COs continued to act out their own values at Eastham. Inmate-inmate justice was legitimated not only by the lack of BTs and the now micro "hands off" doctrine offered by the COs, but also by the revenge and machismo-oriented system (Ekland-Olson 1986:389) controlling the inmates' political, racial and economic subculture. Unofficial authority was also being assumed by the inmate gangs which were increasing in number and which offered protection, identity and esteem for the inmates. Marquart and Crouch (1985:578) reported that prior to the signing of the consent decree there was only one gang at Eastham and after 1983 there were several white and several black gangs. The gangs at Eastham were analogous to Weber's clans.

Although Weber had never mentioned "gangs," he did discuss the relevance of "clans" to the administration of law. He wrote, "It is not necessary that there should be any specifically 'judicial' authority. The clan, as an agency of blood revenge and of the prosecution of feuds, is such an enforcing agency if there exist any sort of rules which govern its behavior in such situations" (1968:35). The gangs at Eastham all had leadership structure, recruitment procedures, such as "kill to get in and die to get out" (Marquart and Crouch 1985:579). They were closed societies with each having common interests and pursuits. They were families that stuck together and protected the membership. Kidder (1983) believed that Weber would look at gang and clan justice as a simplification of law and popular justice and thus a step backward and a "retreat from formal rationality" (189).

Much of the violence, however, occurred outside of gang activity. It was individual inmates using violence as a means to justice and power. At the micro level these seemed to be quite rational motives. Weber (1968:11) defined a motive as "a complex of subjective meaning which seems to the actor himself or to the observer an adequate ground for the conduct in question." The subjective meaning of violence to settle disputes or establish reputation and authority seems an adequate ground in the explanation of post-Ruiz violence at Eastham. As an Eastham inmate asserted, "If somebody has trouble, they're gonna try to stick the other guy. Whoever beats the other to the draw wins" (Marquart and Crouch 1985:577). But again, a system which had resulted in more knifings and increased disciplinary authority in the hands of inmates hardly seems a rational and progressive advancement of the legal system. This reduction of law to one-on-one justice, like gang justice discussed above, seems a partial regression in Weber's (1978:349) order of legal and bureaucratic development.

Weber's formally rational legal system was supposed to function, by and large, calculably or predictably (1968:1395). But just as it hardly seems so above, it also seems to fall short in the area of CO activity at Eastham. The intrusion of Ruiz v. Estelle had resulted in disorder and unpredictability for the COs whose number increased by 150 in the last two months of 1982 (Marquart and Crouch 1985:579). Social control and order which was previously achieved through fear and physical force now had to be informally bargained for with the inmates. COs saw their old authority underminded and believed Ruiz had "turned the place over to the convicts" (Marquart and Crouch 1985:579). 


\subsubsection{Conflicting Ideologies}

Weber might have seen this coming. He wrote that "Formal justice and the 'freedom' which it guarantees are indeed rejected by all the groups ideologically interested in substantive justice" (1968:813). The COs reluctantly tried to enforce the rules, but their supervisors overrode them on the petty violations to avoid clogging the already busy prison disciplinary docket (Marquart 1985:580). While this is understandable motivation and helps explain Eastham's reluctance to carry out the fullest extent of their legal authority, it also sheds further light on the complexity of Weber's theory. While he had seen rationality as the force behind the emergence of modern law and most human activity, he also saw the emergence of, and changes in, law as being effectible by individual actors or political collectivities working out conflicting ideologies (Weber 1968:755).

Just as Weber had described the effect of war on law, the political threat (Ruiz) at Eastham was disrupting the existing social order, "so that it (became) clear to everyone that the things one has been accustomed to are not absolutely sacred" (Weber 1968:771). The COs felt abandoned by their supervisors and threatened by the inmates and the courts. The rationality of Ruiz replaced the traditional social control methods with bureaucratic guidelines and standards. One of the fundamental categories of Weber's rational formal authority was that "administrative acts, decisions, and rules are formulated and recorded in writing" (1968:219). COs made videotapes of their encounters with inmates when they (the COs) anticipated legal reprisals. The videotapes were kept on file along with written reports and photographs to document the physical condition of those involved in the encounter. Weber might have predicted that the administration did not want inmates' claims of brutality to stand up in court. He stated, "The pressing need for security against internal and foreign enemies induces a growing rationalization of lawmaking" (Weber 1968:771). The administration and COs acted to protect their own interests while also protecting those of the inmates.

Despite some behavioral adjustments, it seems that the basic post-Ruiz ideology was still the notion that staff and inmates should be stratified and social order should be maintained. A close look reveals that the staff was, behaviorally at least, adjusting to the new methods and the new political structure created to carry out the Ruiz policies. As the documentation example above indicates, however, the behavioral adjustments were in keeping with both the old pre-Ruiz ideology and the new Ruiz legislative order. But, the new formally rational law was not making it easy for the traditional penal arm of the law to hold on to the old ideology.

\subsubsection{Centralized Authority}

In the three years after the consent decree was signed, Eastham was operating with a much more centralized decision making structure. The warden in pre-Ruiz Eastham was depicted by Marquart and Crouch (1985) as being able to establish many of the policies and procedures. The entire administration could act autonomously. In post-Ruiz, the warden had to carry out directives created and issued by the central office of the Texas Department of Corrections and there was less autonomy permitted in policy implementation. This is characteristic of Weber's modern political community where legitimacy, according to Turner 
(1981:237), was discussed in the context of a "centralized administrative apparatus, a bureaucracy." All the people at Eastham, from the administration down to the inmates, were acting politically and economically. The actions "are characterized as such entirely by the meaning they have for human action in such roles as ends, means, obstacles, and by-products" (Weber 1968:64).

\section{Conclusion}

The general application of Weber's sociology of law, as integrated here to explain the understanding, emergence and impact of law at Eastham, has revealed some causal connections between value and action at several theoretical levels. Through the use of Weber's notion of "verstehen," it has been shown how law was created and viewed as rational from one level and simultaneously seen as irrational or illegal at another. This supports Weber's idea that "law is far from commanding universal respect" (Freund 1968:246). For instance, the prison administration and BTs created law prior to Ruiz, believed it to be rational and upheld it as such. But BT law was seen as illegal from the inmate and state judicial levels and those parties acted accordingly. The Ruiz v. Estelle ruling was seen as rational from the state and inmate levels, but was seen as irrational from the administrative level. People also responded to this law according to their value system. It was not enough, however, to simply say that behavior (the creation of law or the reaction to law) was determined by values, motives and understandings alone. Culture (American or prison) and ideology (social control) were also contributing factors. So too, did the political and bureaucratic issues influence the intentionalities of the actors at both the micro and macro levels.

Prior to Ruiz, the Texas Department of Corrections and Eastham officials ignored a Texas statute prohibiting building tendering. This action clearly served to protect the identity of the penal system, its authoritative boundary and social position. It also legitimated the continuance of a social control ideology and the notion that inmates had no rights. The transitional period, when the ruling came down and initial adjustments were made, served as an example of how laws can be resisted if they are not accompanied by supportive ideology. What went on during this period also showed how a change in the legal order could determine shifts in power. This analysis additionally revealed how formal rationality does not necessarily keep political interests and values out of the judicial system. The three transitional years at Eastham were followed by an increase in violence and bureaucratic behavior. Social control, however, remained the predominate ideology despite behavioral adjustments inside the penal organization that followed the external judicial decision.

This sociology of law at Eastham also revealed what Weber called traditional authority (prison autonomy and building tendering) and rational-legal authority (the intrusion of the court and the centralization of power). The appeal to these ideal types of authority was an extension of Weber's notion of social action (instrumentally rational, value-rational, affectual and traditional). By focusing on this social behavior, it was possible to discuss the actors' motives and understandings at Eastham as they related to the legitimation of the social order, 
the validation of the laws in force (Freund 1968:246), the creation of individual rights and the struggle for power. This inquiry led to an understanding of the reasons why Eastham's legal order and social relationships changed. Although Weber never studied prisons, the methods of analysis used here clearly follow through with his intent (Weber 1968:40) and his conception of a correct causal interpretation which is "arrived at when the overt action and the motives have both been correctly apprehended and at the same time their relationship has become meaningfully comprehensible" (Weber 1968:12).

Weber also recognized, however, that "many ultimate ends or values toward which experience shows that human action may be oriented, often cannot be understood completely" (1968:5). This sociology of law at Eastham probably falls short in this regard, but integrating Weber's different levels of analysis helps to heighten and broaden the available penal research. Weber was certainly aware that not all human behavior was motivated and that many non-motivated factors, such as cultural conditions, affect behavior and "favor or hinder circumstances" (Weber 1947:94). The attention given to macro analysis in this paper provides insight regarding these conditions while highlighting the complexity of delineating multiple social relationships and subjective meanings and melding them into a coherent theoretical explanation of the normative and process facets of law. Two conditions, economic and racial, have hardly been dealt with here and deserve much more Weberian attention.

Finally, it has been suggested that the new bureaucratic legal order at Eastham and the resulting violence may not be as totally rational, calculable, value-free and void of politics as Weber thought legal-rationality might be. Freund (1968) wrote that Weber believed legal formalism offered "the best guarantee of freedom in the defense of individual interests, but often at the expense of the interests of the collectivity and sometimes of those of the state, which was responsible for law and order" (263). Legal formalism was also seen by Weber as possibly tending "towards a rigidity which can generate resistance among the general populace which wants justice" (Kidder 1983:188). It seems that Ruiz may have brought only a limited formal rationalism to Eastham and that the "good faith" (Marquart and Crouch 1985:559) ruling may not, in fact, have brought legal progress there. But, "the use of the term 'progress' is very unfortunate. It can never elevate itself to the sphere of 'ultimate' evaluations" (Weber 1949:39).

\section{References}

Bartels, Koen. 2009. “The Disregard for Weber's Herrschaft: The Relevance of Weber's Ideal

Type of Bureaucracy for the Modern Study of Public Administration." Administrative Theory \& Praxis 31 (4):447-478.

Brakel, Samuel J. 1986. "'Mastering' the Legal Access Rights of Prison Inmates." New England Journal on Criminal and Civil Confinement 12 (1): 1.

Campbell, M.C. 2011. "Politics, Prisons, and Law Enforcement: An Examination of the 
Emergence of 'Law and Order' Politics in Texas.” Law \& Society Review 45(3):631-665.

Champagne, Anthony and K.C. Hass. 1976. "Impact of Johnson v. Avery on Prison Administration." Tennessee Law Review 43: 275.

Chaudhry, Faisal. 2011. “The Promise and Paradox of Max Weber's Legal Sociology: The 'Categories of Legal Thought' as Types of Meaningful Action and The Persistence of the Problem of Judicial Legislation.” Southern California Interdisciplinary Law Journal, 20: 249-288.

Deitch, Michele. 2012. "The Need for Independent Prison Oversight in a Post-PLRA World." Federal Sentencing Reporter 24(4):236-244.

Durkheim, Emile. 1964. The Division of Labor. (Translated by George Simpson). New York, NY: The Free Press.

Ekland-Olson, Sheldon. 1986. "Crowding, Social Control, and Prison Violence: Evidence from The Post-Ruiz Years in Texas." Law \& Society Review 20: 389.

Ekland-Olson, Sheldon and Steve J. Martin. 1988. "Compliance with Court-Ordered Reform." Law \& Society Review 22: 359.

Freund, Julien. 1968. The Sociology of Max Weber. New York: Random House.

Garland, David. 2011. "The Problem of the Body in Modern State Punishment." Social Research 78(3): 767-798.

Giddens, Anthony. 1971. Capitalism and Modern Social Theory. Cambridge: Cambridge University Press.

Inverarity, James M., Pat Lauderdale and Barry C. Feld. 1983. Law and Society: Sociological Perspectives on Criminal Law. Boston: Little, Brown and Company.

Justice, William 1990. “Address: The Origins of Ruiz v. Estelle.” Stanford Law Review 43 (1):1-14.

Justice, William. 1980. Ruiz v. Estelle, 503 F.Supp. 1265

Kidder, Robert L. 1983. Connecting Law and Society. Englewood Cliffs, NJ: Prentice-Hall, Inc.

Kimball, Edward L. and Donald J. Newman. 1968. "Judicial Intervention in Correctional Decisions: Threat and Response." Crime and Delinquency 14: 1. 
Kronman, Anthony T. 1983. Max Weber. Stanford, CA: Stanford University Press.

Marquart, James and Ben Crouch. 1984. "Coopting the Kept: Using Inmates for Social Control in A Southern Prison." Justice Quarterly 1: 491.

Marquart, James and Ben Crouch. 1985. "Judicial Reform and Prisoner Control: The Impact of Ruiz v. Estelle on A Texas Penitentiary." Law \& Society Review 19: 557.

Marx, Karl. 1978. Manifesto of the Communist Party. In The Marx-Engels Reader ( $2^{\text {nd }}$ Edition). (Ed. By R.C. Tucker). New York, NY: W.W. Norton.

Minkkinen, Panu. 2010. “The Legal Academic of Max Weber's Tragic Modernity.” Social \& Legal Studies 19(2):165-182.

Osanloo, Arzoo. 2006. "The Measure of Mercy: Islamic Justice, Sovereign Power, and Human Rights in Iran.” Cultural Anthropology 21 (4):570-602.

Perkinson, Robert. 2010. Texas Tough: The Rise of America's Prison Empire. New York, NY: Metropolitan Books.

Price, Keith and Susan Coleman. 2011. "Narrative of Neglect: Texas Prisons for Men." East Texas Historical Journal XLIX (2):44-68

Qian, X.Y. 2010. "Traditional Chinese Law v. Weberian Legal Rationality.” Max Weber Studies 10 (1):29-45.

Reynolds, Carl. 2002. “The Final Chapters of Ruiz v. Estelle. (Judicial News)”. Corrections Today. 64 (3): 108.

Ross, Jeffrey. 2009-2010. "Resisting the Carceral State: Prisoner Resistance from the Bottom Up.” Social Justice 36(3):28-45.

Sahni, Isher-Paul. 2009. "Max Weber's Sociology of Law: Judge as Mediator.” Journal of Classical Sociology 9(2):209-233.

Schrag, Clarence. 1954. "Leadership among Prison Inmates." American Sociological Review 19: 37.

Stout, Margaret. 2010. "Revisiting the (Lost) Art of Ideal-Typing in Public Administration." Administrative Theory \& Practice 32(4):491-519.

Swedberg, Richard. 2003. "The Changing Picture of Max Weber's Sociology." Annual 
Review of Sociology 29:283-306.

Thomas, Jim. 1984. "Some Aspects of Negotiated Order, Loose Coupling and Mesostructure in Maximum Security Prisons." Symbolic Interaction 213.

Treiber, Hubert. 2012. “On Max Weber's Sociology of Law, Now Known as The Developmental Conditions of the Law. A Review Essay on MWG I/22-3: Recht." Max Weber Studies 12(1):121-138.

Trubek, David. 1986. "Max Weber's Tragic Modernism and the Study of Law in Society." Law \& Society Review 20: 573.

Turner, Jonathan and Leonard Beeghley. 1981. The Emergence of Sociological Theory. Homewood, ILL: The Dorsey Press.

Vago, Steven. 2012. Law and Society (10 ${ }^{\text {th }}$ Edition). Upper Saddle River, NJ. Pearson Education.

Ware, Michael. 1982. "Federal Intervention in State Prisons: The Modern Prison Conditions Case," 19 Houston Law Review 931.

Weber, Max. 1968. Economy and Society, ed. G. Roth and C. Wittich. New York: Bedminster Press.

Weber, Max. 1946. From Max Weber: Essays in Sociology, ed. and trans. H.H. Gerth and C. Wright Mills. New York: Oxford University Press.

Weber, Max. 1978. Max Weber: Selections in Translation, ed. W. Runciman. Cambridge: Cambridge University Press.

Weber, Max. 1947. Max Weber: The Theory of Social and Economic Organization, trans. A.M. Henderson and Talcott Parsons. Glencoe, ILL.: The Free Press.

Weber, Max. 1949. The Methodology of the Social Sciences, ed. E. Shils and H. Finch. Glencoe, ILL: The Free Press.

Wolff, Nancy and Jing Shi. 2009. "Feelings of Safety inside Prison among Male Inmates with Different Victimization Experiences.” Violence and Victims 24(6):800-816. 